Vol.15, No. 57, October, 2020, 971-980

\title{
DESIGN AND MODELLING OF BIODIESEL FUELED COMBUSTION CHAMBER
}

\author{
A. K. Azab ${ }^{1 *}$, M. M. Abd Alaal ${ }^{1}$, M. A. Elkady ${ }^{1}$, and Tamer M. Ismail ${ }^{2}$ \\ ${ }^{1}$ Department of Mechanical Engineering, Al-Azhar University, Cairo, Egypt. \\ ${ }^{2}$ Department of Mechanical Engineering, Suez Canal University, Ismailia, Egypt. \\ *Corresponding Author E-mail: dr.ahmedkhaled@azhar.edu.eg
}

\begin{abstract}
:
Gas turbines combustion chambers (CC) are considered compact, high thermal power generator with low emissions when compared with conventional burners. The hot gases exiting from the gas turbine $\mathrm{CC}$ are of moderate temperature range (900 to $1100 \mathrm{~K}$ ). Large quantities of homogeneous temperature distribution gases can be attained. Many industrial heating applications requires homogeneous and moderate temperature heating medium. The present study main objective is to design a combustor for heating purposes based on the main concept of the technology employed in gas turbine combustor design. The study includes the development of a 3D CFD numerical model for the design purposes. The model is of variable thermal power generation ranging from 50 to $100 \mathrm{~kW}$. The aim of the experimental part of the study is to validate the developed CFD model. The combustor operated with liquid bio fuel as an alternative of depleting fossil fuel, and having better environmental impact. Good agreement was attained between the numerical and the experimental results. The total pressure loss in the combustor was less than 7\%. The exhaust gas analysis for $100 \mathrm{~kW}$ thermal power revealed very low NOx emissions around $0 \mathrm{ppm}$ and low $\mathrm{CO}_{2}$ mole fraction of $1.8 \%$. A homogeneous exit temperature of average $800{ }^{\circ} \mathrm{C}$ was attained. Simulation results indicated that the suggested design produce good mixing and air penetration.
\end{abstract}

KEYWORDS: Combustor, Biofuel, Biodiesel, Emissions, Heating.

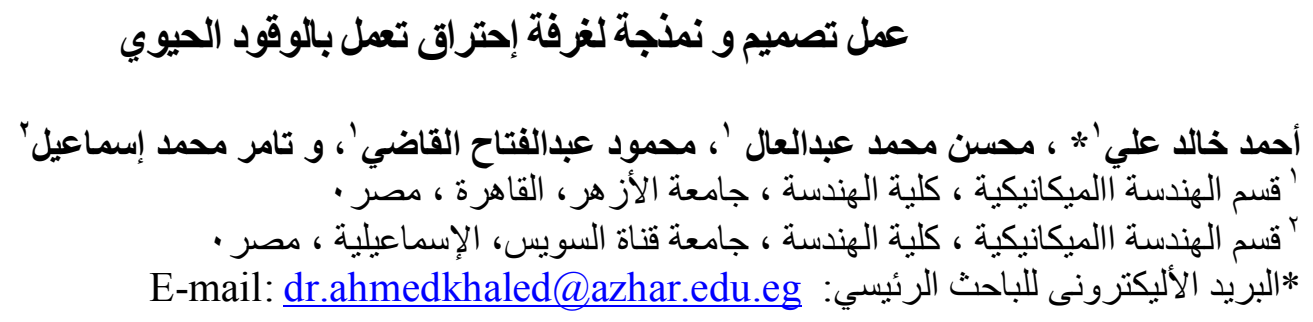

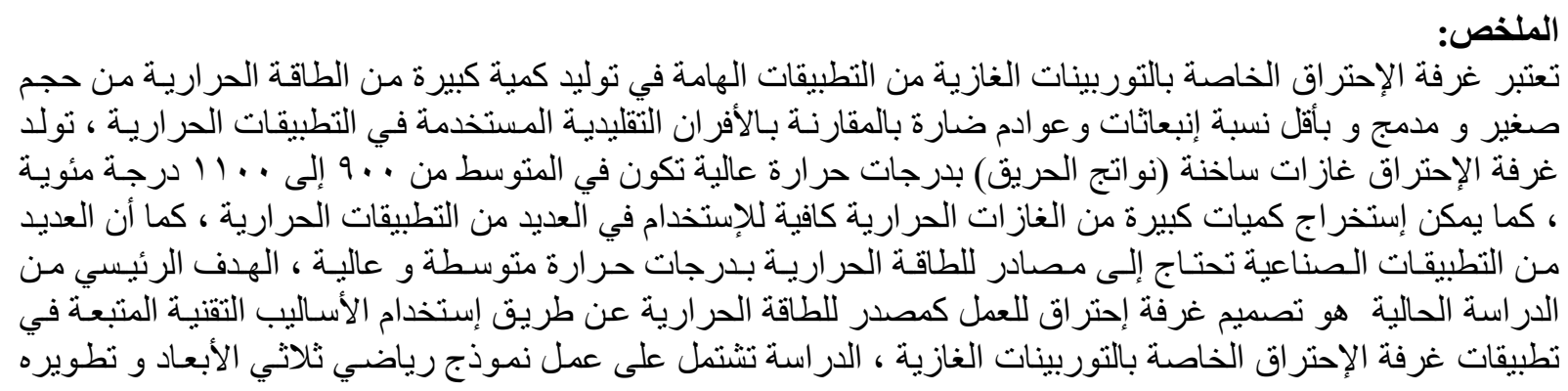




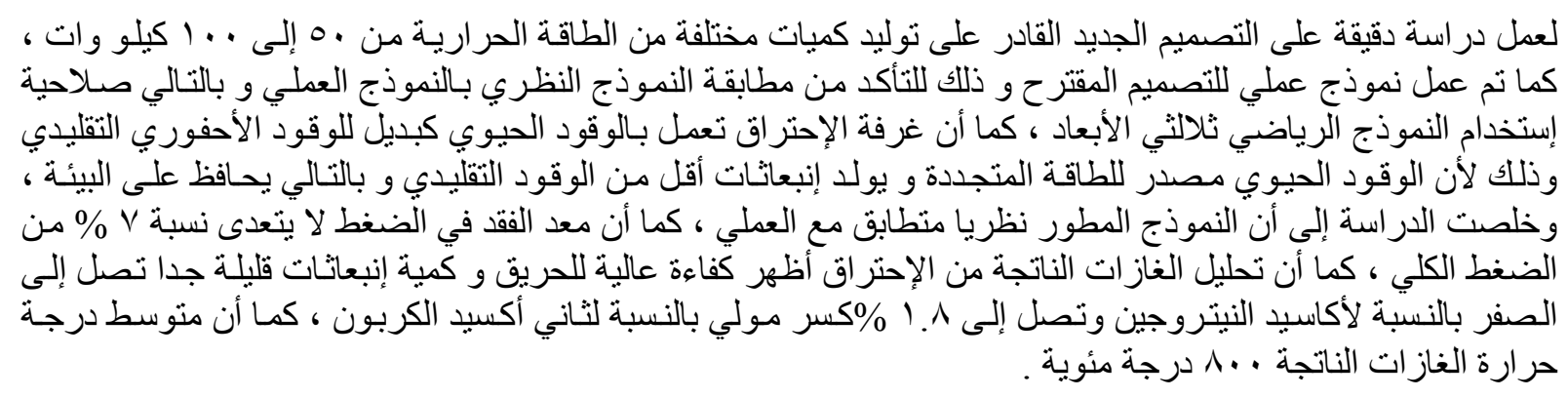

$$
\text { الكلمات المفتاحية : غرفة الاحتراق، الوقود الحيوي، وقود الديزل الحيوي، الإنبعاثات ، الحرارة. }
$$

\section{INTRODUCTION}

Gas turbine combustor have attracted extensive attention in recent years as they exhibits promising potential in heating purposes applications for their great advantages in weight, endurance, and environment impact compared with traditional burner. Combustion techniques are widely investigated to reach a low emission level [1]. Combustors that use different low emissions technologies have been successfully applied to aviation engines [2]. Emission data from engines have proved that lean-burn technology can reduce more NOx emissions than rich-burn technology [3].

Variable geometry combustor is an unconventional method of reducing engine emissions and increasing combustion efficiency based on the active distribution of air among the individual combustion zones. Control of air distribution provides ability to control the flame temperature. Flame temperature has a vital role in $\mathrm{NO}_{\mathrm{X}}$ production, according to thermal $\mathrm{NO}$ Zeldovich mechanism. Larger quantities of air supplied to the primary combustion zones at high combustor power lower the primary-zone temperature, thus reducing $\mathrm{NO}_{\mathrm{X}}$ production. At lower power conditions more air is directed to combustor dilution zone keeping an adequate temperature for low $\mathrm{CO}$ emissions. Additionally, variable geometry combustor with ability to control fuel stoichiometry provides enhanced blowout limits and increases overall combustor operability [4].

Great majority of gas turbine combustor design modification are found in the literature. D. Liua et al. [5] investigated soot formation and combustion characteristics in confined mesoscale combustors of two diameters 4 and $6 \mathrm{~mm}$ between conventional and oxycombustion conditions using high resolution transmissions electron microscopy, thermogravimetric analysis and exhaust gases analysis. A. Fan et al. [6] compared experimentally the dynamics of non-premixed hydrogen-air flames in two Y-shaped cylindrical micro combustors of different horizontal channel lengths ( $\mathrm{L}=100$ and $200 \mathrm{~mm}$ ) then concluded that, the short combustor has a smaller heat loss ratio and a stronger flamewall thermal coupling, which can enhance the combustion intensity and increase the flame propagation speed. X. He et al. [7] described an experimental investigation of the effect of flow conditions on the ignition performance of a conceptual combustor. The successful completion of this testing verified that this novel mixed-flow trapped vortex combustor TVC had reasonable structural design and good ignition performance. W.J. Fan et al. [8] proposed a new ultra-compact combustion mode to further increase the configurable compactness with improvements to the flow and combustion characteristics. The relationships of the flow and combustion characteristics with the combustor configuration were numerically investigated in detail, and the calculation model was verified experimentally.

In recent years, the main target has been on biodiesel, obtained by transesterification of vegetable oils, waste oil, animal fats, and alternative renewable resources. Many researchers investigated various type of combustor fuel to further improve the output thermal power generation and decrease output emissions level from combustion process, A. Kushari et al. [9] studied the effect of using different biofuel blends on gas turbine emissions and performance. C. Wang et al. [10] quantitatively evaluated explosion pressure, deflagration index, maximum pressure rise rate and combustion duration of biofuel in a constant volume combustion chamber (CVCC). At the same time, the effects of initial pressure, initial temperature and equivalence ratio on explosion characteristics of this biofuel was also qualitatively analyzed. 
Z. Zhang et al. [11] reported the gaseous pollutants and Particulate Matter (PM) emissions of a gas turbine combustor burning butyl butyrate and ethanol blends. Aviation kerosene RP-3 and four different biofuels. M. C. Cameretti et al. [12] discussed the potential of a micro gas turbine (MGT) combustor when operated under unconventional conditions, in terms of variation in the fuel supplied. A. Datta et al. [13] studied the changes in the flame characteristics and combustor performance in a cylindrical spray combustor when operated with kerosene and kerosene-ethanol blends. M. Akram et al. [14] analyzed vinas, a byproduct of sugar industry, for its behavior during combustion in a fluidized bed combustor. A. K. Gupta et al. [15] Developed new and renewable biofuels for ultra-low emission gas turbine combustors to secure future power needs. Several fuels are being developed to replace fossil fuels with minimal carbon footprint and pollutants emission. A. G. Muñoz et al. [16] studied a gas turbine combustor that considers two conventional fuels and one biofuel was presented.

The present work main objective is to develop a numerical model to investigate the necessary of the combustor geometry to decrease exit temperature to be suitable for industrial heating purposes, while emitting less air pollutants when utilizing biofuel.

\section{COMPUTATIONAL MODEL}

A computational model is a mathematical model in computational science that requires extensive computational resources to study the behavior of certain process by computer simulation. A model was developed through CFD analysis to achieve the optimum design of the combustor for proper mixing and penetration of combustion elements in the primary, secondary, and dilution zones to achieve high combustion efficiency and uniform exit temperature. During this process, it was ensured that the total pressure remained almost the same as the design based on gas turbine combustor technology that achieve minimum pressure loss during the combustion process. The modeling began with the design of the combustor geometry by using design modeler, followed by combustor mesh and boundary conditions, and ended with finite element model.

The combustor geometry for analysis is a can combustor having an axial flow swirler with 12 aero foil shape vanes at the inlet of combustor provided to maximize the inlet air turbulence and the injector with 6 holes of $5 \mathrm{~mm}$ diameter is provided at the entrance of the primary zone. The length of the liner and number of holes on the liner are designed accordingly and all the dimensions and combustor specifications are provided in table (1). and table (2). Figure (1) show the cross-sectional view of the combustor which is designed according to the design methodology proposed by Lefebvre A. H. and Ballal D. R [4]. Analysis was carried out using ANSYS FLUENT 15. The parametric geometry model was built in ANSYS Design Modeler and consisted of a swirl and combustor liner. Swirl blade was built using three cross- sections (blade profile on the hub, the middle and peripheral diameter).

Results obtained through computation show proper mixing of combustion products with the admission of air through different zone holes and almost uniform temperature at exit.

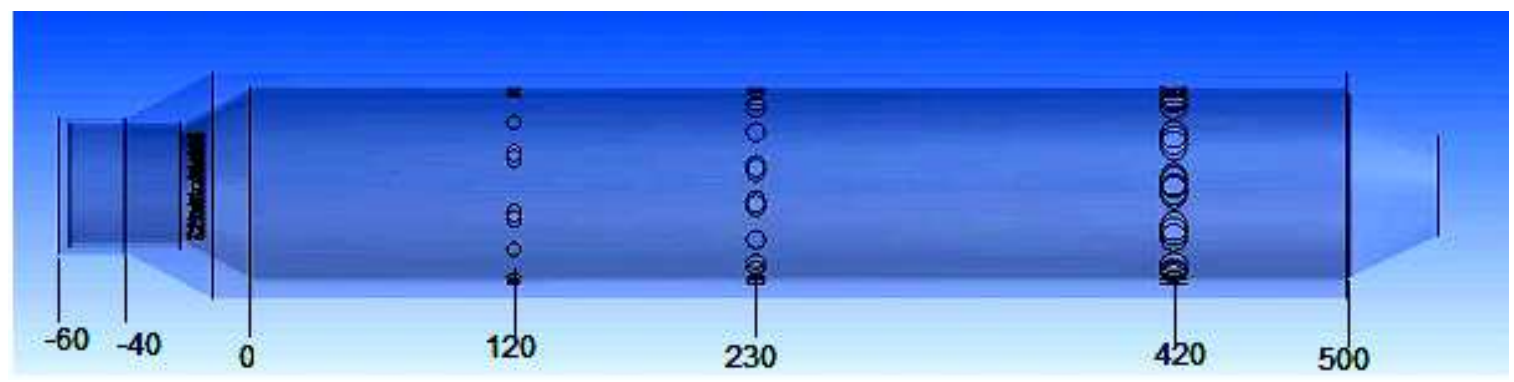

Figure (1) Geometry of the liner of the combustor (All dimensions in millimeters) 
Table (1) Dimensions of various parts of combustor

\begin{tabular}{|l|l|}
\hline \multicolumn{1}{|c|}{ Part } & Dimensions \\
\hline $\begin{array}{l}\text { Hub Diameter, } \\
\mathrm{D}_{\text {hub }}\end{array}$ & $70 \mathrm{~mm}$ \\
\hline $\begin{array}{l}\text { Swirl Diameter, } \\
\mathrm{D}_{\mathrm{sw}}\end{array}$ & $20 \mathrm{~mm}$ \\
\hline Swirl No., $\mathrm{S}_{\mathrm{N}}$ & 1.16 \\
\hline $\mathrm{D}_{\text {sw }} / \mathrm{D}_{\text {hub }}$ & 0.29 \\
\hline Liner length, $\mathrm{L}_{\mathrm{L}}$ & $500 \mathrm{~mm}$ \\
\hline Liner Diameter, $\mathrm{D}_{\mathrm{L}}$ & $82 \mathrm{~mm}$ \\
\hline Case Length & $540 \mathrm{~mm}$ \\
\hline Case Diameter & $102 \mathrm{~mm}$ \\
\hline
\end{tabular}

Table (2) Specifications of the combustor

\begin{tabular}{|l|lc|}
\hline \multicolumn{1}{|c|}{ Design parameter } & \multicolumn{2}{c|}{ Value } \\
\hline Liner diameter & $102 \quad \mathrm{~mm}$ \\
\hline Fuel flow rate & $0.002304 \mathrm{~kg} / \mathrm{s}$ \\
\hline Inlet fuel temperature & 323 & $\mathrm{~K}$ \\
\hline Number of primary holes & 6 & \\
\hline Diameter of primary holes & 5 & $\mathrm{~mm}$ \\
\hline Number of secondary holes & 8 & \\
\hline Diameter of secondary holes & 8 & $\mathrm{~mm}$ \\
\hline Number of dilution holes & 10 \\
\hline Diameter of dilution holes & 12 & $\mathrm{~mm}$ \\
\hline Total inlet air flow rate & 0.15 & $\mathrm{~kg} / \mathrm{s}$ \\
\hline Primary holes FOA & $5 \%$ \\
\hline Secondary holes FOA & $20 \%$ \\
\hline Dilution holes FOA & $50 \%$ \\
\hline Swirler FOA & $25 \%$ \\
\hline Inlet air temperature & 344 & $\mathrm{~K}$ \\
\hline Inlet air pressure & 117 & $\mathrm{kPa}$ \\
\hline $\begin{array}{l}\text { Inlet air Swirl number } \\
\text { (swirler) }\end{array}$ & 0.037 \\
\hline
\end{tabular}

\section{GOVERNING EQUATIONS}

It is well known that; six equations should be solved to model the flow field. These equations are continuity, momentum, energy, species transport, turbulence, and combustion equations. In the present study, flow is treated to be steady, turbulent, compressible and reacting. The governing Navier-Stokes equations (RANS) for the conservation of mass, momentum, energy, and species concentration for the gas, together with an equation of state are approximated for each mesh cell. The resulting set of equations is solved numerically to obtain the flow field, mixing and combustion data. Table (3) shows the computational model for the combustor analysis.

Table (3) Computational mode

\begin{tabular}{|c|c|}
\hline Fluid model & Thermal energy \\
\hline Turbulence model & $\mathrm{k}-\boldsymbol{\varepsilon}$ \\
\hline Species Model & Non premixed combustion \\
\hline Radiation model & Discrete Ordinates \\
\hline Discrete phase model & Interaction with continuous phase \\
\hline
\end{tabular}

The governing equations are defined as;

$\frac{\partial}{\partial x_{j}}\left(\rho u_{j}\right)=0$

$\frac{\sigma}{\sigma x_{i}}\left(\rho u_{i} u_{j}\right)=\frac{\partial p}{\partial x_{i}}+\frac{\partial \tau_{\mathrm{ij}}}{\partial x_{i}}$

where

$\mathrm{u}_{\mathrm{j}}$ is the $\mathrm{jth}$ component of the (mean) velocity vector,

$\rho$ the density of the mixture,

$P$ the pressure

$\tau_{\mathrm{ij}}$ the effective stress tensor.

$\tau_{\mathrm{ij}}$ is defined as 
$\tau_{\mathrm{ij}}=\mu_{\text {eff }}\left(\frac{\partial u_{i}}{\partial x_{i}}+\frac{\partial u u_{j}}{\partial x_{i}}\right)-\frac{2}{3} \mu_{\text {eff }} \frac{\partial u_{1}}{\partial x_{i}} \delta_{i j}$

$\mu_{\text {eff }}=\mu+\mu_{t}$

where

$\mu$ and $\mu_{t}$ are the molecular and turbulent viscosity, respectively.

$\mu_{\tau}$ is determined by a turbulence closure model.

\subsection{Finite Element Model}

ANSYS FLUENT 15.0 was used as solver. The problem is solved as a steady state flow problem, consistent with the RANS turbulence modelling used, which means that relatively large time steps are used in order to achieve a converged solution as quickly as possible.

\subsection{Biodiesel as a fuel of combustor}

Pure biodiesel was used as a combustor fuel; the characteristics of the fuel are shown in table (4) [17] in compare with diesel duel. The incoming air at the specified pressure and temperature enters into the combustion chamber through liner holes, then, reacts with the atomized biodiesel fuel. The effect of providing aero foil swirler at the inlet on flow field and on the combustor, performance will be discussed.

Table (4) Biodiesel fuel analysis [17].

\begin{tabular}{|l|l|l|}
\hline Property & Biodiesel & diesel \\
\hline Relative density & 0.876 & 0.846 \\
\hline Kinematic viscosity $(\mathrm{cSt})$ & 9.60 & 2.60 \\
\hline Calorific value $(\mathrm{MJ} / \mathrm{kg})$ & 36.12 & 42.21 \\
\hline Flash point $\left({ }^{\circ} \mathrm{C}\right)$ & 187 & 52 \\
\hline
\end{tabular}

\section{Model Validation}

The validity of the present modelling outputs data was attained using the experimental measurements of hot gases produced from the designed combustor. The simulation, was carried out using CFD 3D computational model with a structured grid composed of 1575471 cells. The fuel used in the present study is biodiesel. The results presented in column charts and the deviation was calculated according to equation (5). A close relationship between both results was obtained.

Deviation $=\frac{\text { Value }_{\text {exp }}-\text { Value }_{\text {num }}}{\text { Value }_{\text {exp. }}} * \mathbf{1 0 0}=\%$

Figure (2) shows the comparison between computed and experimental results of average temperatures at the combustor exit for variable output of the thermal power. From Figure (2) it is shown that good agreement between both results, where the error does not exceed $4 \%$. 


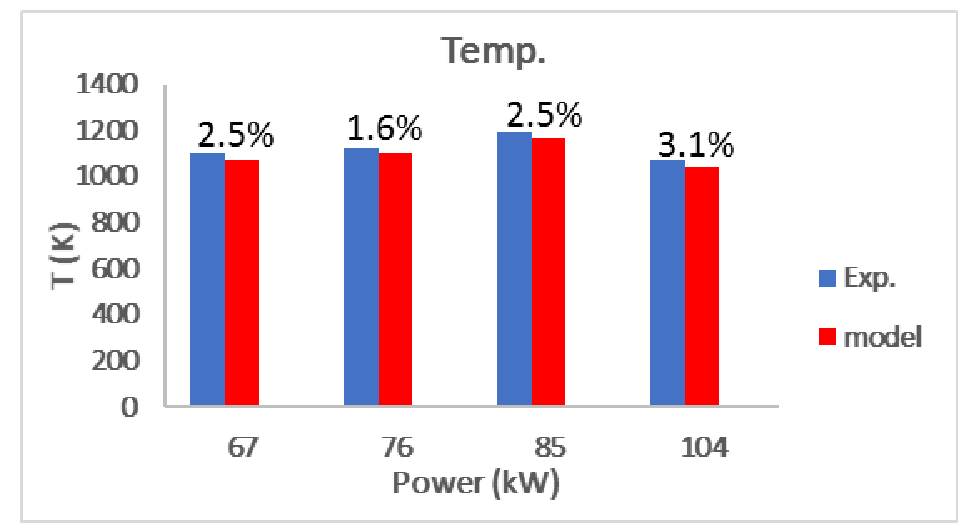

Figure (2) Comparison of the average exit temperature at present model and present experimental

Figure (3) indicates the mole fraction of $\mathrm{CO}_{2}$ at the exit of combustor resulting by the present theoretical model and the present experimental proto type. Although, there is some discrepancy for some values, the computed results agree well with the experiment, at the outlet. Note that the adopted turbulence model, i.e. the transition $\mathrm{k}-\omega$ model which accounts for the intermittency of the flame, is one of the best approaches to predict the minor species like $\mathrm{CO}_{2}$. However, this approach is computationally prohibitive for large multi-objective optimization problems considered here. As a partial remedy, the objective considered here is relative $\mathrm{CO}_{2}$ values with respect to the base case, rather than the dimensional amount of these emissions. This would work even if the model is capable of predicting the correct trend instead of accurate dimensional values of these emissions.

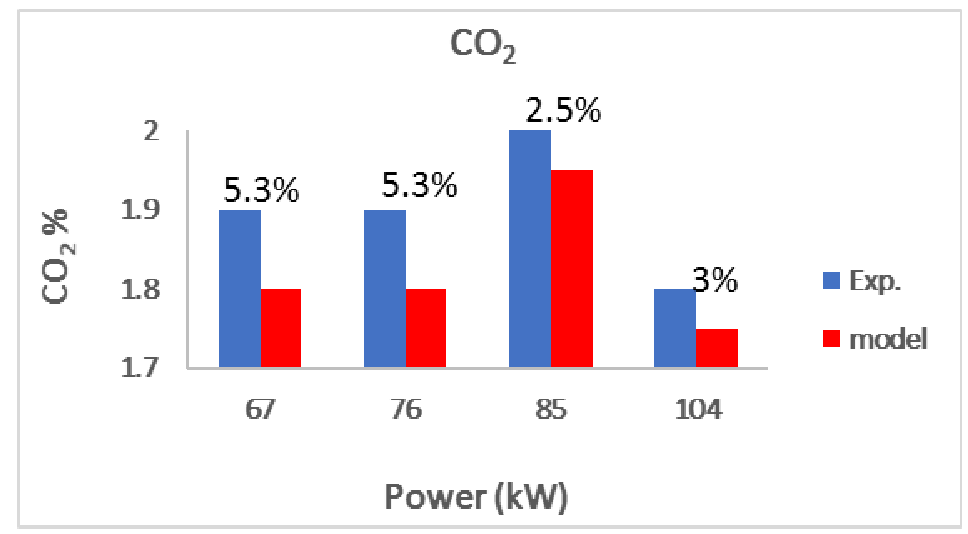

Figure (3) Comparison of average mole fraction of $\mathrm{CO}_{2}$ emission from present model and present

\section{MODEL RESULTS} experimental

This section presents the output results from the model of the $100 \mathrm{~kW}$ combustor. The presented results are at different axial locations within the combustor for the velocity, temperature, and exit emissions. The selected axial sections are six positions based on following illustrative sketch.

Figures (4) shows the resultant velocity (the mean local velocity value at certain point in the domain) distributions at radial and different axial positions in the combustion chamber. One can notice that the primary zone is characterized with low local velocity which increase the residence time of combustion reactions in the primary zone, for both anchoring and mixing of flame. The swirling effect is clear in the tow consecutive positions $X=12 \mathrm{~cm}$, and $X=23 \mathrm{~cm}$, which emphasis mixing and reaction at primary and secondary zones. Then velocities levels get higher in the dilution zone (at $X=42 \mathrm{~cm}$ ) compared to the primary zone, as more air enters through the dilution zone from velocity contour for reacting flow in radial direction. 


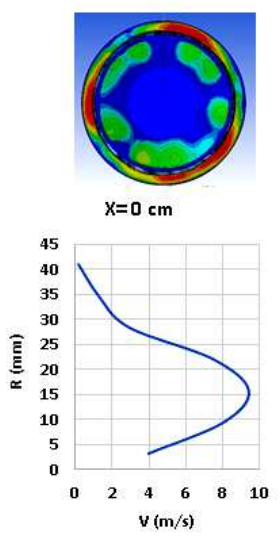

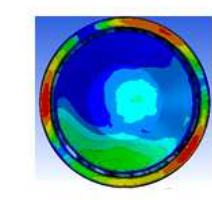

$\mathrm{x}=10 \mathrm{~cm}$
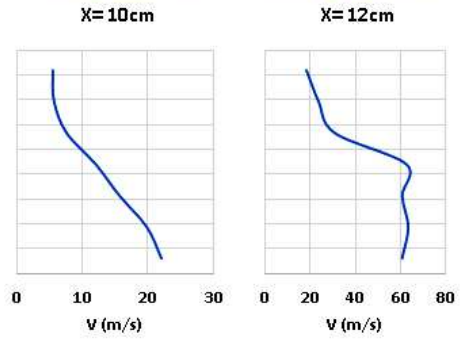

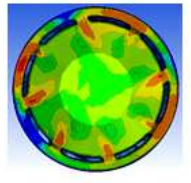

$\mathrm{x}=23 \mathrm{~cm}$

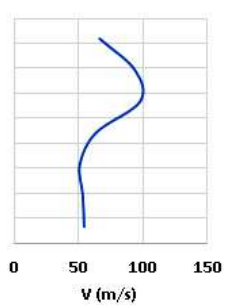

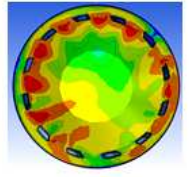

$\mathrm{x}=42 \mathrm{~cm}$

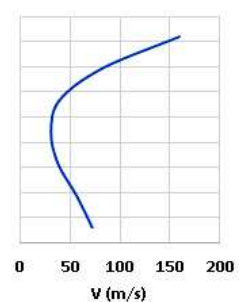

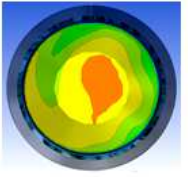

$\mathrm{x}=50 \mathrm{~cm}$

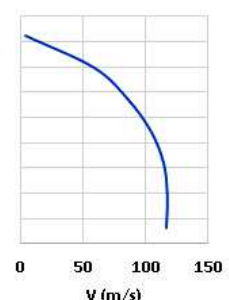

Figure (4) Radial velocity contour and its distribution at different distance along combustor length.

Figure (5) presents the contours of flow field, for longitudinal section of the combustor. The region of high swirling flow inside the combustor visualizes a large swirling flow structure attached to the swirler of the combustor. Inside this structure, there is a region of negative axial velocity. The region shown in figure (4) in primary zone at $X=12 \mathrm{~cm}$ is called primary recirculating zone (PRZ) which is the characteristic of high fuel mass flow rate cases. The PRZ region in this case is composed of two pairs of counter-rotating cells. At the interface of PRZ and the high-swirl region, a high-shear region exists which produces considerable values of turbulent kinetic energy. Due to the relatively small angle of liner dome, the expansion of inflow occurs gradually and there is no corner recirculation zone (CRZ) inside the chamber.

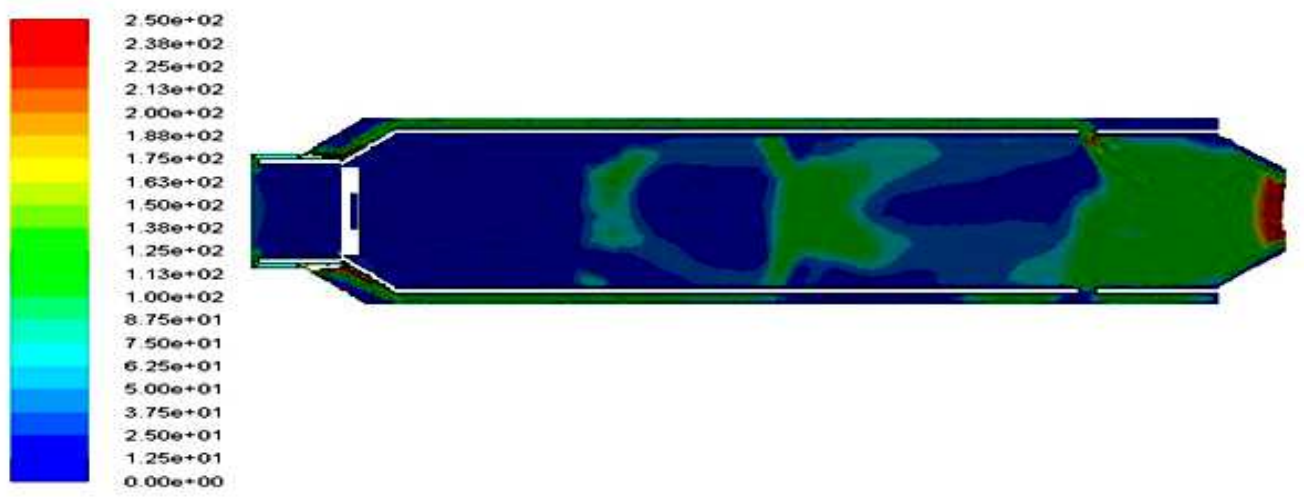

Figure (5) axial velocity contours

Figures (6) shows the temperature distributions at radial, and axial locations, and contours of the combustion chamber. From these figures it can be observed that, the flame surface approaches to the dome walls. This is because the effect of swirl on the high flow rate of air causes the high shear region to move towards the dome walls. As mentioned above, this region is also the region of high turbulent kinetic energy which promotes mixing and reaction rates (in non-premixed regime). Therefore, the flame surface is located in this region, near walls, and special care must be taken to prevent the dome walls from burning. This is the reason why larger cooling flow rates were assigned to the secondary cooling holes region. 


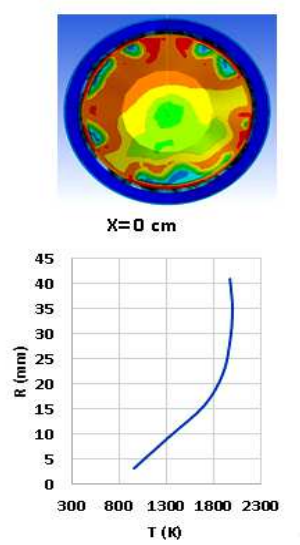

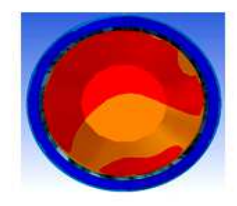

$\mathrm{x}=10 \mathrm{~cm}$

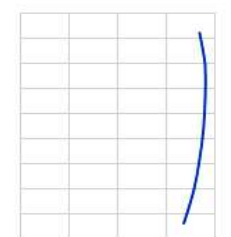

300800130018002300

$T(\boldsymbol{k})$

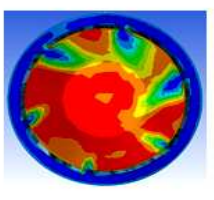

$\mathrm{x}=12 \mathrm{~cm}$

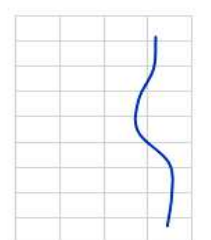

300800130018002300

$\mathrm{T}(\mathrm{k})$

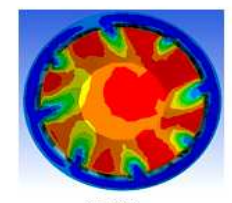

$\mathrm{x}=23 \mathrm{~cm}$

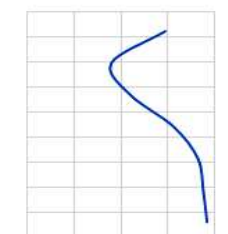

300800130018002300

$T\left(\mathbf{C}^{2}\right)$

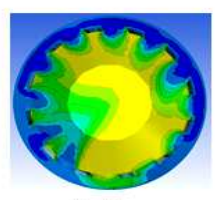

$x=42 \mathrm{~cm}$

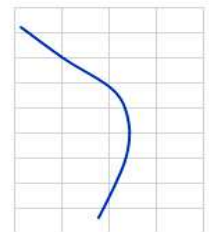

$300 \quad 800 \quad 1300 \quad 1800 \quad 2300$

$\mathrm{T}$ ( $\mathrm{k})$

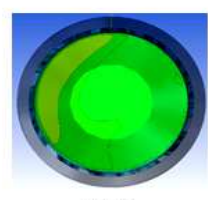

$x=50 \mathrm{~cm}$

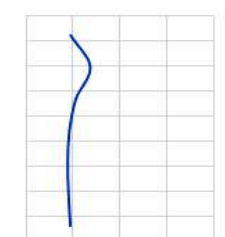

$300 \quad 800130018002300$

$\mathrm{T}(\mathrm{k})$

Figure (6) Radial temperature contour and its distribution at different distance along combustor length.

Figure (7) presents the temperature contours at longitudinal combustor section. It's clear that, the primary and secondary zones are characterized by higher temperature levels, that is due to the fact that, these zones are responsible for the combustion reactions. Downstream the temperature levels go down and the minimum temperatures are attained at exit of the combustion chamber which is required by the design.

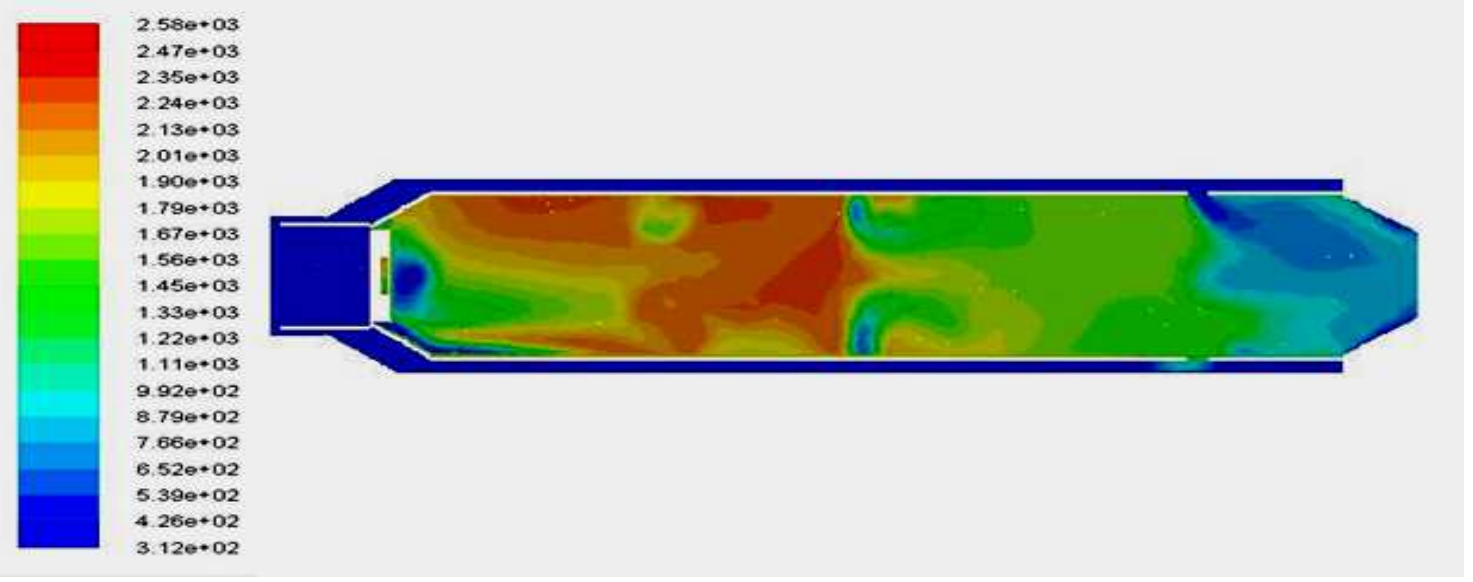

Figure (7) Axial temperature contours.

\section{CONCLUSIONS}

In this research, the computational fluid dynamics is used to model the non-premixed combustion process of gas turbine combustor. The developed model is validated with the experimental results. This is to investigate the effect of $100 \mathrm{~kW}$ non-premixed combustor geometry, swirler shape, and the inlet air velocity on the flame temperature distribution, and the species mole fraction considering variable properties. The following conclusions could be deduced from the course of the present study

1. The new designed combustor using low pressurized combustion air $(6 \mathrm{kPa})$ can produce high thermal power to volume ratio this is due to the intensified combustion.

2. The hot gases generating from combustor is 5 times larger than traditional burner due to the high overall air-fuel ratio, with homogenous temperature range of $(900-1100$ $\mathrm{K}$ ) which is very suitable to many industrial applications including food industries.

3. The temperature of primary zone is almost around the range of adiabatic flame temperature $(2300 \mathrm{~K})$ which stabilize and anchoring the flame.

4. CFD approach for the proposed combustor is suitable and reliable for the such combustor design simulation. 


\section{REFERENCES}

1. Mongia, H. C. (2010). On continuous NOx reduction of aero-propulsion engines. 48th AIAA Aerospace Sciences Meeting Including the New Horizons Forum and Aerospace Exposition, (January). https://doi.org/10.2514/6.2010-1329

2. Haselbach, F., \& Parker, R. (2012). Hot end technology for advanced, low emission large civil aircraft engines. 28th Congress of the International Council of the Aeronautical Sciences 2012, ICAS 2012, 3, 2479-2490.

3. Foust, M. J., Thomsen, D., Stickles, R., Cooper, C., \& Dodds, W. (2012). Development of the GE aviation low emissions TAPS combustor for next generation aircraft engines. 50th AIAA Aerospace Sciences Meeting Including the New Horizons Forum and Aerospace Exposition, 2020. https://doi.org/10.2514/6.2012-936

4. A.H. Lefebvre, D.R. Ballal, (2010). Gas Turbine Combustion: Alternative Fuels and Emissions, third ed., CRC Press.

5. Chen, M., Liu, D., \& Jiang, B. (2020). Soot formation and combustion characteristics in confined mesoscale combustors under conventional and oxy-combustion conditions (O2/N2 and O2/CO2). Fuel, 264(December 2019). https://doi.org/10.1016/j.fuel.2019.116808

6. Xiang, Y., Wang, S., Yuan, Z., \& Fan, A. (2019). Effects of channel length on propagation behaviors of non-premixed $\mathrm{H} 2$-air flames in Y-shaped micro combustors. International Journal of Hydrogen Energy, (xxxx). https://doi.org/10.1016/j.ijhydene.2019.11.147

7. Jiang, P., \& He, X. (2020). Ignition characteristics of a novel mixed- fl ow trapped vortex combustor for turboshaft engine. 261(August 2019), 1-10.

8. Zhang, R. C., Bai, N. J., Fan, W. J., Huang, X. Y., \& Fan, X. Q. (2019). Influence of flame stabilization and fuel injection modes on the fl ow and combustion characteristics of gas turbine combustor with cavity. 189.

9. Sundararaj, R. H., Kumar, R. D., Raut, A. K., Sekar, T. C., Pandey, V., Kushari, A., \& Puri, S. K. (2019). Combustion and emission characteristics from biojet fuel blends in a gas turbine combustor. Energy, 182, 689-705. https://doi.org/10.1016/j.energy.2019.06.060

10. Xu, C., Wang, H., Li, X., Zhou, W., Wang, C., \& Wang, S. (2019). Explosion characteristics of a pyrolysis biofuel derived from rice husk. 369(January), 324-333.

11. Chen, L., Zhang, Z., Lu, Y., Zhang, C., Zhang, X., Zhang, C., \& Paul, A. (2017). Experimental study of the gaseous and particulate matter emissions from a gas turbine combustor burning butyl butyrate and ethanol blends. 195, 693-701.

12. Abagnale, C., Cameretti, M. C., Robbio, R. De, \& Tuccillo, R. (2016). CFD Study of a MGT Combustor supplied with Syngas. 101(September), 933-940. https://doi.org/10.1016/j.egypro.2016.11.118.

13. Patra, J., Ghose, P., Datta, A., Das, M., Ganguly, R., Sen, S., \& Chatterjee, S. (2015). Studies of combustion characteristics of kerosene ethanol blends in an axi-symmetric combustor. Fuel, 144, 205-213. https://doi.org/10.1016/j.fuel.2014.12.036.

14. Akram, M., Tan, C. K., Garwood, R., \& Thai, S. M. (2015). Vinasse - A potential biofuel - Cofiring with coal in a fluidised bed combustor. 158, 1006-1015.

15. Khalil, A. E. E., \& Gupta, A. K. (2014). Clean combustion in gas turbine engines using Butyl Nonanoate biofuel. 116, 522-528.

16. Alfaro-ayala, J. A., Gallegos-muñoz, A., Uribe-ramírez, A. R., \& Belman-flores, J. M. (2013). Use of bioethanol in a gas turbine combustor. 61, 481-490.

17. Jaichandar, S., \& Annamalai, K. (2011). The Status of Biodiesel as an Alternative Fuel for Diesel Engine - An Overview. Journal of Sustainable Energy \& Environment, 2, 71-75.

\section{ABBREVIATION \\ BB Butyl Butyrate \\ CC Combustion Chamber \\ CFB Circulating Fluidized Bed \\ CFD Computational Fluid Dynamics \\ CRN Chemical Reactor Network}




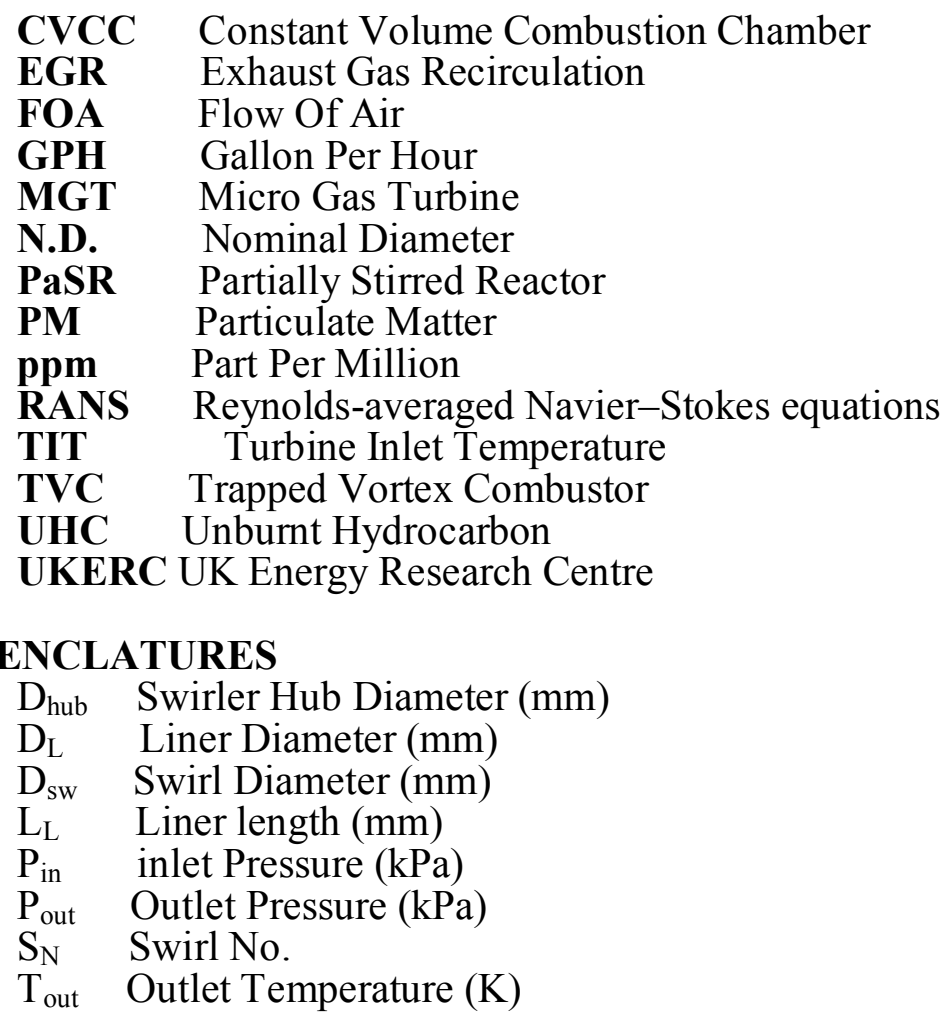

\section{SYMBOLS}

$\Phi \quad$ Equivalence Ratio

k- $\varepsilon \quad$ K epsilon model 